\title{
Clinical Profile and Outcome of COVID-19 in Children at a Tertiary Hospital, Dhaka
}

\author{
S MAHBUBA $^{1}$, CHOWDHURY S $^{2}$, ALAMIN A $^{3}$
}

\begin{abstract}
:
Background: Since the first detection on $8^{\text {th }}$ March 2020 in Bangladesh, the number of cases is rising alarmingly. The paediatric population is also getting infected in Bangladesh. So far there is no study of COVID in children in this country.

Aim: This study reports on clinical profile, laboratory findings and outcomes of COVID-19 children admitted to Combined Military Hospital (CMH), Dhaka.
\end{abstract}

Materials and Methods: In this prospective observational study, RT-PCR confirmed fifty COVID-19 patients aged below twelve years were included. Relevant investigations were done in the Armed Forces Institute of Pathology (AFIP). Data were collected from patients and/or their attendants by a structured questionnaire.

Results: Mean age was $59.96 \pm 43.24$ months, $48 \%$ were male and $52 \%$ were female. Predominant symptoms were fever (44\%), cough (26\%), anosmia (26\%) and diarrhea (12\%).

Introduction:

Novel COVID-19 is an illness caused by severe acute respiratory syndrome coronavirus 2 (SARS-CoV-2). Common symptoms are dry cough, fever and myalgia ${ }^{1}$. On $11^{\text {th }}$ March 2020, WHO recognized this disease as a pandemic ${ }^{2}$. First case of COVID-19 of Bangladesh was detected in Dhaka, on $8^{\text {th }}$ March, 2020, since then numbers are raising alarmingly ${ }^{3}$. However, most studies have focused on adults and only a small number of pediatric patients with COVID-19 have been reported. Children are less commonly affected by SARS-CoV- $2^{4}$.

a. Big. Gen. Mahbuba Sultana, Advisor, Specialist in Paediatrics and Peiatric Pulmonologist, Dept. of Paediatrics, $\mathrm{CMH}$, Dhaka.

b. Lt. Col. Sayla Chowdhury, Classified Child Specialist, Dept. of Paediatrics, CMH, Dhaka.

c. Lt. Col. Abdullah Al-Amin, Classified Child Specialist, Dept. of Paediatrics, $\mathrm{CMH}$, Dhaka.

Address of Correspondence: Big. Gen. Mahbuba Sultana, Advisor, Specialist in Paediatrics and Peiatric Pulmonologist, Dept. of Paediatrics, CMH, Dhaka. Phone: 01741103454, Email: smahbuba366@gmail.com

Received: 21 Sept., 2020

Accepted: 4 May, 2021
There was neutropenia in $66 \%$ and lymphocytosis in $84 \%$ of cases. Mean neutrophil and lymphocyte counts were $38 \pm 13 \%$ and $52.5 \pm 13 \%$, respectively. Significantly raised CRP observed in 14\% and high serum procalcitonin was in $10 \%$ of cases. Serum LDH, D-Dimer and ferritin were raised in $80 \%, 34 \%$ and $6 \%$ of affected children, respectively. The majority (98\%) of the children were improved and discharged from the hospital. One child died in this cohort.

Conclusion: Fever and cough were the predominant symptoms of COVID-19 affected children in this study. Lymphocytosis and neutropenia were two important laboratory finding. Death in COVID-19 is also not uncommon.

Keywords: COVID-19 in children, clinical feature, comorbidity, laboratory findings, outcome

(J Bangladesh Coll Phys Surg 2021; 39: 154-159) DOI: https://doi.org/10.3329/jbcps.v39i3.54162

The Chinese CDC reported among 72,314 cases, only $2 \%$ were less than 19 years of age ${ }^{4}$. In general, the clinical presentation has been less severe in pediatric cases when compared to adult cases, and the reason for this difference is unknown. De Souza TH et al found $14.2 \%$ asymptomatic, $36.3 \%$ mild, $46.0 \%$ moderate, $2.1 \%$ severe, and $1.2 \%$ critical cases in children. The most prevalent symptom was fever (47.5\%), followed by cough $(41.5 \%)$, nasal symptoms (11.2\%), diarrhea $(8.1 \%)$, and nausea/vomiting $(7.1 \%)^{5}$. COVID-19 in children from six provinces in northern China are mainly caused by close family contact. Clinical manifestations and laboratory examination results may be nonspecific. Close contact history, nucleic acid detection and chest imaging are important bases for diagnosis of 2019-nCoV infection. After treatment, the short-term prognosis is good in COVID-19 in children ${ }^{6}$. From a small case series of 9 mothers who were infected with SARS-CoV2, there was no evidence that SARS-CoV-2 can be vertically transmitted ${ }^{7}$. In a systematic review of laboratory-confirmed cases of COVID-19 in children 
$<18$ years $^{8}$ the complete blood count was normal in most children; 17 percent had low white blood cell count and 13 percent had either neutropenia or lymphocytopenia. ${ }^{9}$ In a series of 157 children with COVID-19, elevated Serum Lactate Dehydrogenase( S.LDH) was another common laboratory findings ${ }^{10}$. Elevated inflammatory markers (e.g. C - reactive protein (CRP), procalcitonin, serum ferritin, D-dimer) at admission or during hospitalization may be associated with severe disease in children ${ }^{11}$.

The aim of this study was to reports on demographic profile, clinical presentation, laboratory findings and outcomes of COVID-19 patients admitted in Combined Military Hospital (CMH), Dhaka.

\section{Methods:}

In this prospective observational study. RT-PCR confirmed COVID-19 children, who admitted in CMH Dhaka since $13^{\text {th }}$ April to 4th Aug 2020 were enrolled in this study. Data were collected in this period from patients and/or their attendants and attending physicians through face to face and/or telephone interview. Data were collected in a structured questionnaire, after having appropriate consent from parent. This study included all COVID-19 children from Newborn to 12 years of age irrespective of their disease severity along with their affected parents. Fifty six consecutive patients met inclusion criteria through convenient sampling from ward and six patients were excluded. The statistical analysis was done by SPSS version 23.0.

The protocol was approved by the Ethical and Scientific Committee of CMH, Dhaka. Demographic data (age, sex, etc.), clinical data (symptoms on admission, comorbidities, laboratory findings and outcome etc.) were collected and analyzed. Qualitative variables such as fever, cough etc. were expressed as frequency and percentage. Quantitative variables like age, durations, etc. were expressed as mean \pm standard deviation (SD).

\section{Results:}

Fifty patients were included in the study over a period of four months. Mean age was $59.96 \pm 43.24$ months, $48 \%$ were male and $52 \%$ were female (Table-I).
Table-I

\begin{tabular}{lcc}
\multicolumn{3}{l}{ Age and sex distribution of studied children $(n=50)$} \\
Age & Number & Percentage \\
\hline Newborn (0-28 days) & 3 & 6 \\
1mon to 1yr & 5 & 10 \\
1yr-2yr & 5 & 10 \\
$2 \mathrm{yr}-5 \mathrm{yr}$ & 15 & 30 \\
5yr-10yr & 17 & 34 \\
10yr-12yr & 6 & 12 \\
Mean & 59.96 months & \\
SD & 43.239 & \\
Minimum & Newborn & \\
Maximum & 12 years & \\
Sex & Frequency & Percentage \\
Male & 24 & 48 \\
Female & 26 & 52 \\
\hline
\end{tabular}

Among fifty RT-PCR positive cases, thirty three (66\%) were symptomatic and seventeen (34\%) were asymptomatic

Patients got admitted with fever (44\%), cough (26\%), Diarrhoea (12\%), Nausea and vomiting (10\%), anosmia (26\%), chest pain (4\%) sore throat (8) constipation and abdominal pain (2) headache (2) and runny nose (6). (Table-II)

\section{Table-II}

COVID-19 symptoms of the study children $(n=50)$

COVID-19 symptoms $\quad$ Frequency Percentage

\begin{tabular}{lcc}
\hline Fever & 22 & 44 \\
Cough & 13 & 26 \\
Difficulty in Breathing & 4 & 8 \\
Diarrhea & 6 & 12 \\
Nausea and Vomiting & 5 & 10 \\
Anosmia & 13 & 26 \\
Chest pain & 2 & 4 \\
Sore throat & 4 & 8 \\
Constipation and abdominal pain1 & 2 & \\
Headache & 1 & 2 \\
Runny nose & 3 & 6 \\
\hline
\end{tabular}

Out of fifty cases $34 \%$ were admitted for less than 10 days, $44 \%$ were admitted for $10-14$ days and $22 \%$ were admitted for more than 14 days. Duration of hospital stay ranged from 1 to 21 days with a mean of $10.96 \pm .18$ days. (Figure: 1) 


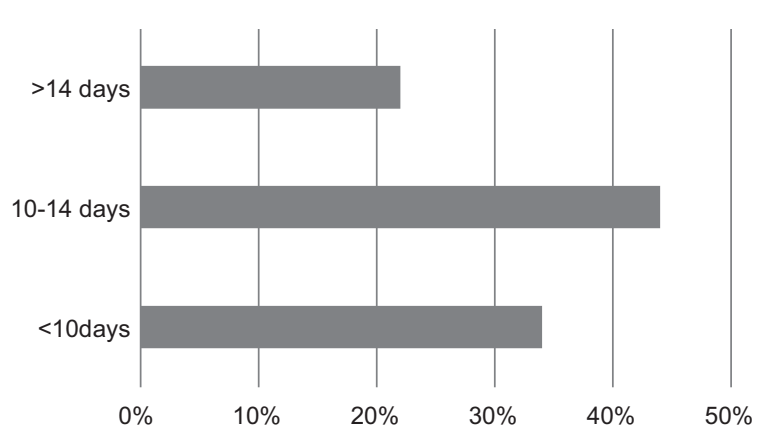

Fig.- 1: Duration of Hospital Stay $(n=50)$

Out of fifty cases thirteen (26\%) cases were associated with co-morbidities like congenital heart disease (10\%) followed by bronchial asthma, hereditary hemolytic anaemia, adenoid and ROP. (Table-III)

\section{Table-III}

\begin{tabular}{lcc}
$\begin{array}{r}\text { Distribution of comorbidities among } \\
\text { children }(n=13)\end{array}$ & $\begin{array}{c}\text { studied } \\
\text { Association } \\
\text { CHD }\end{array}$ \\
Frequency & Percentage \\
Hereditary hemolytic anaemia & 5 & 38.4 \\
Bronchial asthma & 4 & 7.6 \\
Enlarged adenoid & 2 & 30.7 \\
ROP & 1 & 15.3 \\
\hline
\end{tabular}

Out of fifty patient 10 patients $(20 \%)$ had increased total leukocyte count, whereas 5 patients $(10 \%)$ had decreased total leukocyte count, although most of the cases $(70 \%)$ had leukocyte count in normal range. (Figure-2)

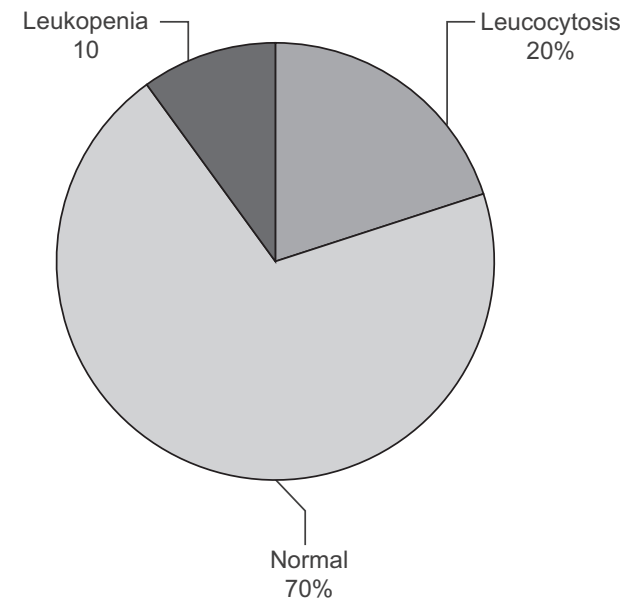

Fig.-2 : Leucocyte count in COVID 19 children
Of the fifty cases seventeen $(34 \%)$ cases had normal count, thirty three $(66 \%)$ cases had decreased neutrophil count, but no patient had increased neutrophil count. In case of lymphocyte count forty two (84\%) cases had increased, 8 patients (16\%) had normal and five case $(10 \%)$ patients had decreased lymphocyte count. Mean neutrophil and lymphocyte count was $38 \pm 13 \%$ and $52.5 \pm 13 \%$ respectively. (Figure- 3 )

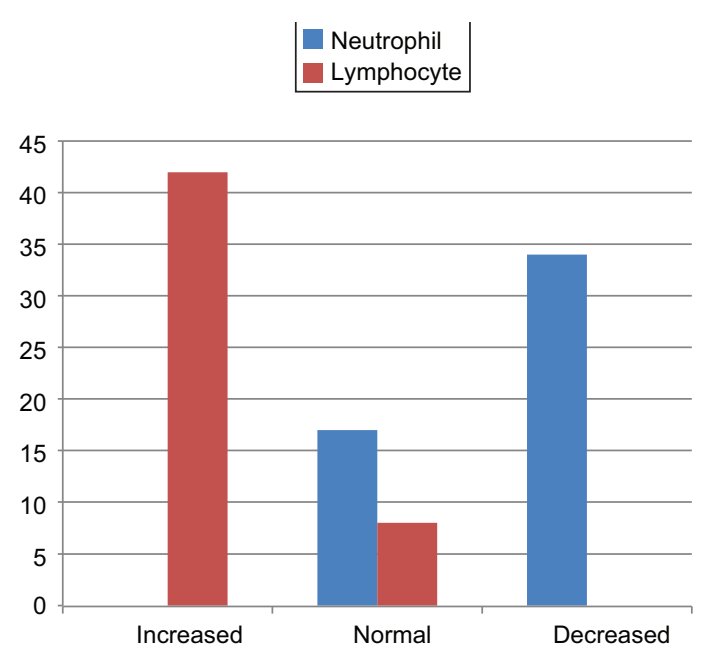

Fig.-3: Distribution of Neutrophil and Lymphocyte count in studied children

Of the fifty cases seven (14\%) cases had positive CRP.(Table IV)

Table-IV

Level of CRP among the COVID-19 children $(n=50)$

\begin{tabular}{lcc} 
CRP & Frequency & Percentage \\
\hline Positive & 7 & 14 \\
Negative & 43 & 86 \\
\hline
\end{tabular}

Out of the fifty cases two $(04 \%)$ cases had high S. creatinine level with a mean of $0.47 \pm 0.19 \mathrm{mg} / \mathrm{dl}$ and five $(10 \%)$ cases had high S. procalcitonin level with mean procalcitonin level was $0.0656 \pm 0.4 \mathrm{ng} / \mathrm{ml}$. Seventy (34\%) cases had high D-Dimer level with a mean of $0.95 \pm 1.09$ $\mu \mathrm{g} / \mathrm{ml}$ and forty (80\%) cases had high S. LDH. Out of fifty cases, only three $(6 \%)$ cases had a high $\mathrm{S}$. ferritin. (Table: V) 
Table-V

\begin{tabular}{|c|c|c|}
\hline \multicolumn{3}{|c|}{$\begin{array}{l}\text { Laboratory markers of COVID-19 } \\
\text { studied children }(n=50)\end{array}$} \\
\hline S. creatinine & Frequency & Percentage \\
\hline High & 2 & 4 \\
\hline Normal & 48 & 96 \\
\hline $\begin{array}{l}\text { S. Procalcitonin } \\
\text { High } \\
\text { Normal }(<.0 .15 \mathrm{ng} / \mathrm{mL})\end{array}$ & $\begin{array}{c}5 \\
45\end{array}$ & $\begin{array}{l}10 \\
90\end{array}$ \\
\hline $\begin{array}{l}\text { D-Dimer } \\
\text { High } \\
\text { Normal }(0.4-2.27 \mu \mathrm{g} / \mathrm{ml})\end{array}$ & $\begin{array}{l}17 \\
33\end{array}$ & $\begin{array}{l}34 \\
66\end{array}$ \\
\hline $\begin{array}{l}\text { S. LDH } \\
\text { High } \\
\text { Normal }(225-480 \mathrm{U} / \mathrm{L})\end{array}$ & $\begin{array}{l}40 \\
10\end{array}$ & $\begin{array}{l}80 \\
20\end{array}$ \\
\hline $\begin{array}{l}\text { S. Ferritin } \\
\text { High } \\
\text { Normal (Male: 28-397) } \\
\text { Female:( 6-159) }\end{array}$ & $\begin{array}{c}3 \\
47\end{array}$ & $\begin{array}{c}6 \\
94\end{array}$ \\
\hline
\end{tabular}

Chest X-ray was done in all cases and in all cases these were normal, therefore no HRCT chest was done.

Out of all fifty patient 49 patients were improved and discharged. Only one child died in this cohort.

Discussion:

Different studies show COVID-19 is generally a mild disease in children, including infants. However, a small proportion develops severe disease requiring ICU care and prolonged ventilation, although the outcome is rarely fatal. ${ }^{12}$

In this study among 50 patient 24 patient (48\%) were male and 26 patients (52\%) were female. COVID- 19 can be found at any age, starting from newborn to adult. In this study mean age was $59.96 \pm 43.24$ months. Dong et al. found median age of 7 years which is almost relevant to this study ${ }^{13}$.

Among fifty RT-PCR positive children, thirty-three (66\%) were symptomatic and seventeen (34\%) were asymptomatic found in this study. However, Carmen et al. in a review, showed that $14.3 \%$ of cases were asymptomatic, and the remaining $85.7 \%$ were symptomatic, which differs from this study ${ }^{14}$.

Predominant symptoms COVID-19 of this study were fever (44\%) followed by cough, anosmia, diarrhea, vomiting, anosmia and sore throat. Carmen et al. observed a similar presentation with the present study. ${ }^{14}$ They showed that fever $(59.3 \%)$ was the most typical symptom, followed by cough, rhinorrhea or pharyngeal congestion, diarrhea and sore throats were less common in their study.

Out of fifty cases, thirteen (26\%) children were associated with co-morbid conditions. These were congenital heart disease, hereditary hemolytic anaemia, bronchial asthma, enlarged adenoid and ROP. Zachariah $\mathrm{P}$ et al. showed, $61 \%$ of the children had comorbidities in their study. ${ }^{11}$ Obesity was the most common (22\%) and asthma, sickle cell disease, cardiac disease, and diabetes were the other comorbidities that partially matched with the current study.

Wu et al. in a review, found abnormalities in leukocyte count about $31.08 \%$ of children and $13.51 \%$ presented with abnormal lymphocyte count ${ }^{15}$. In the present study, $34 \%$ of cases had normal and $66 \%$ had decreased neutrophil count. In lymphocyte count, $84 \%$ of cases had increased, $16 \%$ had normal and $10 \%$ of patients had reduced lymphocyte count, which differs from this study. Henry et al. showed changes in leukocyte counts, $32 \%$ of the mild cases in their study. Based on data obtained from COVID-19 studies, leukocyte indices in children appear inconsistent, differing from those reported in adults that highlight specific leukocyte trends' which partially matched with this study ${ }^{18}$.

In the present study, seven (14\%) patients had positive CRP, forty (80\%) patients had high S. LDH and five $(10 \%)$ patients had high S. procalcitonin level. Michael $\mathrm{H}$ et al. showed in severe disease, CRP, procalcitonin and $\mathrm{LDH}$ were frequently elevated ${ }^{17}$. In contrast, $\mathrm{Li} \mathrm{C}$ et al. showed elevated LDH level at admission was found as an independent risk factor in adults for the severity and mortality of COVID-19 in their studies ${ }^{17}$. Lin Z et al. study reported higher serum ferritin levels in severe COVID-19 cases suggested features of systemic inflammatory reaction ${ }^{18}$. In our study, $6 \%$ of children had high S. ferritin. In this study, severe presentation of COVID-19 was not documented and biochemical markers were significantly raised, which was matched with the previous study.

Forty-nine (98\%) patients were improved and discharged, only one patient (2\%) died. Thus, the coronavirus disease 2019 in children seemed to have a milder disease course and better prognosis than adults. 
In addition, deaths were rare, which was similar to this study $^{19}$.

Limitations: Small sample size and inclusion criteria were not severity based. Children affected with COVID 19 infection were admitted due to fear of the uncertain clinical profile and outcome. Initially, there was a social stigma related to the infectivity of the disease, which created panic in society.

\section{Conclusion:}

Clinical profile of COVID 19 in children was mild and the outcome was good. Fever and cough were the predominant findings of COVID-19 affected children in this study. In contrast to the COVID in adult lymphocytosis and neutropenia were two important laboratory findings. The inflammatory markers were raised as expected. This study reports death from COVID-19 also. This study should encourage other academicians to have more researches in this field.

\section{Acknowledgment:}

Lt Col S M Nurul Irfan, Medical officer, Bangladesh Navy.

\section{References:}

1. Chen N, Zhou M, Dong X, Qu J, Gong F, Han Y, et al. Epidemiological and clinical characteristics of 99 cases of 2019 novel coronavirus pneumonia in Wuhan, China: a descriptive study. Lancet 2020:395:507-513.https://doi.org/ 10.1016/S0140-6736(20)30211-7

2. Ding Y, Yan H, Guo W(2020) Clinical characteristics of children with COVID-19: A meta-analysis. Front. Pediatr 2020 8:431. doi:10.3389/fped.2020.00431 https://doi.org/ $10.3389 /$ fped.2020.00431, PMid:32719759, PMCid:PMC7350605

3. Mowla SGM , Azad KAK, Kabir A, Biswas S, Islam MR, Banik GC, et al. Clinical Profile Of 100 Confirmed Covid19 Patients Admitted In Dhaka Medical College Hospital, Dhaka, Bangladesh. J Bangladesh Coll Phys Surg 2020; 38: 29-36. doi.org/10.3329/Jbcps.V38i0.47445https://doi.org/ $10.3329 /$ jbcps.v38i0.47445

4. Wu Z, McGoogan JM. Characteristics of and important lessons from the coronavirus disease 2019 (COVID-19) outbreak in China: summary of a report of 72314 cases from the Chinese center for disease control and prevention. JAMA 2020;323(13):1239-1242. doi:10.1001/ jama.2020.2648. https://doi.org/10.1001/jama.2020.2648, PMid:32091533

5. De Souza TH, Nadal JA, N Nogueria RJ, Pereira RM, Brando $\mathrm{MB}$, et al. Clinical manifestations of children with COVID19: A systematic review. Pediatric Pulmonology
2020; 55:1892-1899. https://doi.org/10.1002/ppul.24885, PMid:32492251, PMCid:PMC7300659

6. Wang D, Ju XL, Xie F, Lu Y,Li FY,Huang HH, et al. Clinical Analysis of 31 Cases of 2019 Novel Coronavirus Infection in Children From Six Provinces (autonomous Region) of Northern China. Chinese Journal of Pediatrics 2020, 58: 4, 269-274.

7. Chen H, Guo J, Wang C, et al. Clinical characteristics and intrauterine vertical transmission potential of COVID-19 infection in nine pregnant women: a retrospective review of medical records. The Lancet. 2020:1-7.

8. Liguoro I, Pilotto C, Bonanni M, Ferrari MF, Pusiol A, Cogo P, et al. SARS-COV-2 infection in children and newborns: a systematic review. Eur J Pediatr 2020; 179:1029. https://doi.org/10.1007/s00431-020-03684-7 PMid:32424745 PMCid:PMC7234446

9. Venturini E, Palmas G, Montagnani C, Chiappinni E, Galli L, Cietra F, et al. Severe neutropenia in infants with severe acute respiratory syndrome caused by the novel coronavirus 2019 infection. J Pediatr 2020; 222:259., https://doi.org/ 10.1016/j.jpeds. 2020.04.051, PMid: 32444222 PMCid:PMC7236669

10. Wu H, Zhu H, Yuan C, Yao C, Luo W, Shen X, et al. Clinical and Immune Features of Hospitalized Pediatric Patients With Coronavirus Disease 2019 (COVID-19) in Wuhan, China. JAMA Netw Open. 2020;3(6):e2010895. doi:10.1001/jamanetworkopen.2020.10895 https:// pubmed.ncbi.nlm.nih.gov/32492165/)https://doi.org/ 10.1001/jamanetworkopen.2020.10895, PMid:32492165 PMCid:PMC7272117

11. Zachariah P, Johnson CL, Halabi KC, Ahn D, Fishcer A, Sen AI, et al. Epidemiology, Clinical Features, and Disease Severity in Patients With Coronavirus Disease 2019 (COVID-19) in a Children's Hospital in New York City, New York. JAMA Pediatr 2020; :e202430. https://doi.org/ 10.1001/jamapediatrics.2020.2430PMid:32492092 ,PMCid:PMC7270880

12. Florian Götzinger, Santiago-Gercia B, Noguera-Jullian A, Lanaspa M, Lancella L, Calo Carducci FI, et al. COVID-19 in children and adolescents in Europe: a multinational, multicentre cohort study. Lancet Child Adolesc Health 2020; 4: 653-61 Published Online June 25, 2020 https://doi.org/ 10.1016/S2352-4642(20) 30177-2)

13. Dong Y, Mo X, Hu Y, Qi X, Jiang F, Jiang Z, et al. Epidemiology of COVID-19 Among Children in China. Pediatrics. 2020;145(6): e20200702 https://doi.org/ 10.1542/peds.2020-0702, PMid:32179660

14. Carmen Lok Tung Ho, Peter Oligbu, Olakunle Ojubolamo, Muhammad Pervaiz, Godwin Oligbu. Clinical Characteristics of Children with COVID-19. AIMS Public Health , 2020, 7(2): 258-273. doi: 10.3934/publichealth.2020022) https:/ /doi.org/10.3934/publichealth.2020022 PMid:32617354 ,PMCid:PMC7327402 
15. Wu Q, Xing Y, Shi L, Xing Q, Wang W, Wang Y et al. Coinfection and Other Clinical Characteristics of COVID19 in Children. Pediatrics. 2020;146(1):e20200961) https:/ /doi.org/10.1542/peds.2020-0961, PMid:32376725

16. Henry BM, Benoit S W, Santos de Oliveira HM, Hsieh WC, Benoit J, Ballout R A, et al. Laboratory Abnormalities in Children with Mild and Severe Coronavirus Disease 2019 (COVID-19): a pooled analysis and review. Clinical Biochemistry 2020; 81:1-8. https://doi.org/10.1016/ j.clinbiochem.2020.05.012, PMid:32473151 PMCid: PMC 7251358

17. Li C, Ye J, Chen Q, Hu W, Wang L, Fan Y, et al. Elevated Lactate Dehydrogenase (LDH) level as an independent risk factor for the severity and mortality of COVID-19.
Aging (Albany NY). 2020; 12:15670-15681. https://doi.org/ 10.18632/aging.103770) https://doi.org/10.18632/aging. 103770 PMid:32805722, PMCid:PMC7467395

18. Lin Z, Long F, Yang Y, Chen X, Xu L, Yang M. Serum ferritin as an independent risk factor for severity in COVID19 patients [published online ahead of print, 2020 Jun 24]. J Infect. 2020; S0163-4453(20)30434-5.doi: 10.1016/ j.jinf.2020.06.053, https://doi.org/10.1016/j.jinf.2020. 06.053 PMid:32592705, PMCid:PMC7313486

19. Jonas F. Ludvigsson Systematic review of COVID-19 in children shows milder cases and a better prognosis than adults Acta Paediatrica. 2020;109:1088-1095. https:// doi.org/10.1111/apa.15270, PMid:32202343 PMCid: PMC 7228328 